Research Report No. 28/2009

\title{
Global Anti-Corruption Regimes: Why Law Schools May Want to Take a Multi-Jurisdiction Approach
}

D. Alison von Rosenvinge

Follow this and additional works at: http:/ / digitalcommons.osgoode.yorku.ca/clpe

\section{Recommended Citation}

von Rosenvinge, D. Alison, "Global Anti-Corruption Regimes: Why Law Schools May Want to Take a Multi-Jurisdiction Approach" (2009). Comparative Research in Law \& Political Economy. Research Paper No. 28/2009.

http://digitalcommons.osgoode.yorku.ca/clpe/141 


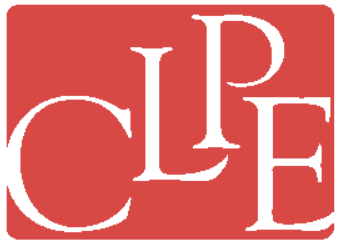

\section{Comparative Research in Law \& Political Economy}

CLPE RESEARCH PAPER 28/2009

\section{Alison von Rosenvinge}

Global Anti-Corruption Regimes: Why Law Schools may Want to Take a Multi-Jurisdiction Approach

EDITORS: Peer Zumbansen (Osgoode Hall Law School, Toronto, Director, Comparative Research in Law and Political Economy, York University), John W. Cioffi (University of California at Riverside), Nassim Nasser (Osgoode Hall Law School, Toronto, Production Editor)

Also available at: http://www.germanlawjournal.com 



\section{German Law Journal}

Global Anti-Corruption Regimes: Why Law Schools may want to take a Multi-Jurisdiction Approach

Alison von Rosenvinge

10 German Law Journal 785 (2009), available at:

http://www.germanlawjournal.com/article.php?id=1120

This article was originally published in Volume 10, Number 7 of the German Law Journal as part of the journal's $10^{\text {th }}$ anniversary symposium on "Transnationalizing Legal Education" edited by Nadia Chiesa, Adam de Luca, and Bernadette Maheandiran. 
CLPE Research Paper 28/2009

Vol. 05 No. 04(2009)

Alison von Rosenvinge

\title{
Global Anti-CoRruption Regimes: Why LaW Schools May Want to TAKE A MULTI-JURISDiCTION APPROACH
}

\begin{abstract}
The legal fight against bribery and corruption has evolved from the solitary effort of the United States with its Foreign Corrupt Practices Act (FCPA) to a global legal endeavor. Corporations are frequently engaged in transnational deals that require them to understand their obligations under a web of anti-corruption regulations with penalties ranging from fines in the tens of millions of dollars to life imprisonment. Although the market for legal services has changed to match client needs, the curriculum at most U.S. law schools has not. This paper explores the relationship between transnational business and legal services and legal education in the United States.
\end{abstract}

First, the article offers a comparative analysis of the main anti-corruption regimes, including the Foreign Corrupt Practices Act, The Organization for Economic Co-Operation and Development Convention on Combating Bribery of Foreign Public Officials in International Business Transactions, United Nations Convention Against Corruption, The Organization of American States Inter-American Convention Against Corruption, Council of Europe Criminal and Civil Law Conventions on Corruption and The African Union Convention on Preventing and Combating Corruption.

Second, this paper analyzes how the legal market in the United States has responded to the global regulatory environment and provides an empirical study of the what anti-corruption legal services the twenty-five largest U.S. law firms provide their clients.

Finally, the paper presents a rough outline of a possible curriculum change and suggests that U.S. law schools would be well-advised to allow interested students to pursue multi-jurisdictional specialization in certain regulatory practice areas.

Keywords: Legal education, Curriculum change, Anti-corruption regimes,

JEL classification: K10, K40

Alison von Rosenvinge

Research Scholar, New York Law School, Ph.D. and J.D. University of Pennsylvania.

Email: alison.von.rosenvinge@gmail.com 



\title{
SPECIAL ISSUE: TRANSNATIONALIZING LEGAL EDUCATION
}

\section{Global Anti-Corruption Regimes: Why law schools may want to take a multi-jurisdictional approach}

\author{
By D. Alison von Rosenvinge*
}

\section{A. Introduction}

In the last fifteen years, the legal fight against bribery and corruption has evolved from the solitary effort of the United States with its Foreign Corrupt Practices Act (FCPA), 15 U.S.C. $\S \S 78$ et seq., to a global legal endeavor. During the same period of time, corporations have become increasingly engaged in transnational deals that require them to understand their obligations under a web of anti-corruption regulations. The stakes for businesses are high: fines can range in the tens of millions of dollars and individuals found guilty of corruption may be imprisoned for life. ${ }^{1}$

Although the market for legal services has changed dramatically during this time, the curriculum at U.S. law schools has not. Most U.S. law schools prioritize teaching students how to "think like a lawyer" over teaching practical skills and issue-specific law. ${ }^{2}$ New lawyers in many legal practice areas, including international law, lack practical skills and legal knowledge when they begin their careers. ${ }^{3}$ The gap between what legal services law firms are providing their clients and what American law students learn in law school is well-

\footnotetext{
* Research Scholar, New York Law School, Ph.D. and J.D. University of Pennsylvania. Email: alison.von.rosenvinge@gmail.com.

${ }^{1}$ In April 2007, Baker Hughes disgorged profits of approximately USD 33 million and paid a criminal fine of USD 11 million. United States Securities and Exchange Commission Press Release: SEC Charges Baker Hughes with Foreign Bribery and with Violating 2001 Cease-and-Desist Order available at: http://www.sec.gov/news/ press/2007/2007-77.htm (last visited Apr. 29, 2009). In 2009, Kang Huijun, former deputy of Shanghai's Pudong New Area District, was sentenced to life imprisonment for taking bribes. Xinhua News Agency, February 3, 2009 available at: http://www.china.org.cn/china/news/2009-02/03/content_17218040.htm (last visited Apr. 29, 2009).

2 See generally, An Educational Continuum, Report of the Task Force on Law Schools and the Profession: Narrowing the Gap, American Bar Association Section of Legal Education and Admission to the Bar (the MacCrate Report), July 1992 available at: http://www.abanet.org/legaled/publications/onlinepubs/maccrate.html \#Introduction (last visited Apr. 29, 2009).

${ }^{3}$ Stephen J. Friedman, A Practical Manifesto for Legal Education: Law schools are professional schools, so let's teach these students something, Legal Times, Sept. 28, 2005 available at: http://www.law.com/ jsp/article.jsp?id=1127811912465 (last visited Apr. 29, 2009) (Little has been done to help "those new lawyers whose work is transactional, or who focus on advising businesses or individuals and families, or who specialize in real estate or international transactions.") (last visited Apr. 29, 2009).
} 
documented. ${ }^{4}$ As industries and financial institutions have "gone global," the needs of legal clients frequently cross jurisdictional borders. The largest consumers of legal services must comply with a wide variety of regulations. A truly effective legal education must not only provide interested students with practical and analytical skills, but also may require a cross-jurisdictional background. ${ }^{5}$

This paper uses the anti-corruption regulatory framework as a case study for how legal education could better track the legal market. Anti-corruption regimes provide a useful model for multinational curriculum offerings because unlike many newer regulatory regimes, the first anti-corruption law, the FCPA, is over three decades old. When the FCPA was enacted in 1977, most countries opposed it as a classic example of the U.S. overreaching its bounds. U.S. corporations opposed it because they thought it made it harder for them to compete internationally. ${ }^{6}$ By the 1990s, some academics were arguing that it was not only bad law, but bad business. ${ }^{7}$ Yet, by the mid-1990s, other countries and supranational organizations began adopting their own anti-corruption treaties. Since the

\footnotetext{
${ }^{4}$ The MacCrate Report at Introduction ("It has long been apparent that American law schools cannot reasonably be expected to shoulder the task of converting even very able students into full-fledged lawyers licensed to handle legal matters. Thus, a gap develops between the expectation and the reality, resulting in complaints and recriminations from legal educators and practicing lawyers. The lament of the practicing bar is a steady refrain: 'They can't draft a contract, they can't write, they've never seen a summons, the professors have never been inside a courtroom.' Law schools offer the traditional responses: 'We teach them how to think, we're not trade schools, we're centers of scholarship and learning, practice is best taught by practitioners."') 1992 available at: http://www.abanet.org/legaled/publications/onlinepubs/maccrate.html\#Introduction (last visited Apr. 29, 2009).

${ }^{5}$ Stephen J. Friedman, A Practical Manifesto for Legal Education. available at: http://www.law.com/jsp/ article.jsp?id=1127811912465 (last visited Apr. 29, 2009).

${ }^{6}$ See generally, Lay-Person's Guide to FCPA, Foreign Corrupt Practices Act Bribery Provisions available at: www.usdoj.gov/criminal/fraud/docs/dojdocb.html (last visited Apr. 29, 2009) ("Following the passage of the FCPA, the Congress became concerned that American companies were operating at a disadvantage compared to foreign companies who routinely paid bribes and, in some countries, were permitted to deduct the cost of such bribes as business expenses on their taxes."); Macleans A. Geo-JaJa and Garth L. Mangum, The Foreign Corrupt Practices Act's Consequences for U.S. Trade: The Nigerian Example, Africa Economic Analysis, at p. 3 available at: http://www.afbis.com/analysis/corruption.htm (last visited Apr. 29, 2009) ("the FCPA has received support as well as criticism for putting American firms at a competitive disadvantage in world business where the bribe is an accepted facilitator").

${ }^{7}$ In the early 1990s, there were a number of articles arguing that U.S. companies were disadvantaged in international business because they were unable to bribe foreign officials while their competitors did so. See generally, Peter Semler, U.S. Companies Find Corruption a Competitor, JOURNAL OF COMMERCE (J. Com.) 8A (Apr. 18, 1994) (U.S. companies are increasingly losing business abroad as foreign companies unhindered by U.S. anticorruption laws win contracts through bribes and other practices); E. Grey Lewis, Continued Official U.S. Pressure Called Key to Winning Kuwait Reconstruction Contracts, 9 INTERNATIONAL TRADE REPORTER (Int'I Trade Rep.) 472, 472 (Mar. 27, 1991) (Lewis [an attorney] asserted that a major obstacle to U.S. participation in Kuwait's recovery is the constraint placed on doing business by the U.S. Foreign Corrupt Practices Act, which major U.S. competitors do not have to follow.); Stephen Muffler, Proposing a Treaty on the Prevention of International Corrupt Payments: Cloning the Foreign Corrupt Practices Act is not the Answer, 1 InTERnATIONAL LaW StUdents Association Journal of INTERNATIONAL AND COMPARATIVE LAW (ILSA J. INT'L \& COMP. L. ) 3 (1995).
} 
early 2000s, the United States itself has stepped up both the number of investigations and the vigor of its enforcement. ${ }^{8}$ Far from being a unique outlier, the FCPA was just the first of many anti-corruption regimes. Anti-corruption regulation seems to be here to stay.

This article offers a comparative analysis of the main anti-corruption regimes, how the legal market in the United States has responded to the regulatory environment, and suggests a shift in legal education to allow for multi-jurisdictional specialization in certain regulatory issue areas. The article is divided into three parts: Part I provides background information on the major existing anti-corruption legal regimes; Part II offers an overview of how U.S. law firms are responding to these multi-jurisdictional regulatory regimes; and Part III suggests that traditional state-based legal education should be augmented to provide interested students with a multi-jurisdictional practical education in certain regulatory regimes, using the anti-corruption regulatory framework as an example.

\section{B. Anti-Corruption Regimes}

Anti-corruption regulations have been adopted by state governments, international organizations and regional governmental entities. ${ }^{9}$ Corporations conducting business across borders can be faced with a number of legal requirements enforced by different entities. What may be an illicit act under one regime may not be under another. This section provides a brief summary of the major regimes.

\section{State-Based Anti-Corruption Regime: The Foreign Corrupt Practices Act}

From 1977 until the mid-1990s, the FCPA was the only law that targeted international corruption. In early 1974, investigations headed by the United States Securities and Exchange Commission (SEC) linked incidents relating to the Watergate scandal under President Richard Nixon with money laundering through foreign countries, and with using campaign funds to bribe foreign officials. ${ }^{10}$ In 1976, the SEC submitted its now-famous "Report on Questionable and Illegal Corporate Payments and Practices" to the United

\footnotetext{
${ }^{8}$ See generally, Danforth Newcomb and Philip Urofsky, Recent Trends and Patterns in FCPA Enforcement (as of February 13, 2008) available at: http://www.shearman.com/files/upload/LT-021308-Recent-Trends-and-Patternsin-FCPA-Enforcement-February-2008.pdf (last visited Apr. 29, 2009); Andrew Osterland, U.S. targeting execs in bribe probes: Feds' push to investigate companies for corrupt practices overseas

${ }^{9}$ In this paper, "regional organizations" are defined as multi-state organizations whose member states are limited to states within a certain geographical area and "international organizations" are multi-state organizations whose membership is not limited by geographic region.

${ }^{10}$ See Alejandro Posados, Combating Corruption Under International Law, 10 DUKE JOURNAL OF COMPARATIVE AND INTERnATIONAL LAW (DUKE J. COMP. \& INT'L L). 345, 348-49 (2000); Thomas R. Snider and Won Kidane, Combating Corruption Through International Law in Africa: A Comparative Analysis, 40 CORNELL INTERNATIONAL LAW JOURNAL (CORNELL INT'L L.J.) 691, 696-97 (2007).
} 
States Senate Committee on Banking, Housing and Urban Affairs. As a result of the SEC investigations, over 400 U.S. companies admitted to having made questionable or illegal payments worth more than USD 300 million to foreign government officials. The illicit payments ranged from straight-out bribery of high government officials to "facilitating" payments to government functionaries. ${ }^{11}$ The report stated that over $60 \%$ of the companies analyzed had been involved in making some kind of payments to foreign officials. ${ }^{12}$

In 1977, the U.S. Congress enacted the FCPA to stop bribery of foreign officials and to restore public confidence in American business. The FCPA has two components: (1) the accounting provisions and (2) the anti-bribery provisions. The accounting provisions apply to any company that has publicly-traded securities in the United States and requires those companies to maintain records that accurately and fairly represent the company's transactions. The anti-bribery provisions make it unlawful to bribe or attempt to bribe a foreign government official.

In order to constitute a violation of the FCPA anti-bribery provisions, five elements must be met. First, the anti-bribery provisions apply to domestic concerns, ${ }^{13}$ issuers, ${ }^{14}$ and any person (including foreign individuals or entities) making or authorizing an illegal payment. Second, the person or entity authorizing or making the payment must have a corrupt intent and the payment must be intended to induce the public official to improperly direct business. A person can violate the FCPA with only a promise or offer of an improper payment, even if the payment is not successful in retaining business. Third, the FCPA categorically prohibits paying, offering, or promising to pay money or anything of value. Fourth, the anti-bribery provisions prohibit corrupt payments to public officials only (not private business people). The definition of public officials includes any officer, employee or functionary of a foreign government, public international organization, or any department or agency thereof, or any person acting in an official capacity. Finally, the anti-bribery provisions prohibit payments made in order to obtain or retain business. ${ }^{15}$

\footnotetext{
${ }^{11}$ United States House Report (H.R. Report) No. 95-114, 1-2 (1977).

${ }^{12}$ Posados, supra note $10,355$.

${ }^{13}$ Defined as any individual who is a citizen, national or resident of the United States, or any corporation, partnership, association, joint-stock company, business trust, unincorporated organization or sole proprietorship which has its principal place of business in the United States or which is organized under the laws of a state, territory, possession or commonwealth of the United States.

${ }^{14}$ Defined as a corporation that has issued securities that has been registered in the United States or who is required to file periodic reports with the SEC.

${ }^{15}$ See generally, Lay-Person's Guide to FCPA, supra, note 6.
} 


\section{Anti-Corruption Conventions of International Organizations}

1. The Organization for Economic Co-Operation and Development Convention on Combating Bribery of Foreign Public Officials in International Business Transactions

The Organization for Economic Co-Operation and Development (OECD) Anti-Bribery Convention entered into force on February $15,1999 .{ }^{16}$ While the OECD was not the first international convention to combat bribery, it is a significant regime because its members are the world's major economic players.

The OECD Anti-Bribery Convention requires signatories to criminalize intentionally offering, promising or giving any undue pecuniary or other advantage, whether directly or through intermediaries, to a foreign public official, for that official or for a third party, in order that the official act or refrain from acting in relation to the performance of official duties, in order to obtain or retain business or other improper advantage in the conduct of international business. ${ }^{17}$

Of the 17 articles that comprise the OECD Convention, the first 12 have substantive significance (the last five deal with the legalities of multilateral treaties). The first article deals exclusively with bribery. Like the FCPA, the OECD Convention applies to monetary and non-monetary payments and payments made through intermediaries. ${ }^{18}$ The OECD Anti-Bribery Convention also exempts "facilitation payments" made to low-level public officials to expedite routine governmental functions. ${ }^{19}$ The second article obligates each party to implement any steps necessary to "establish the liability of legal persons" for bribery. $^{20}$ The third article sets out the requirements for sanctions, including that "[t]he range of penalties shall be comparable to that applicable to the bribery of the Party's own public officials and shall, in the case of natural persons, include the deprivation of liberty sufficient to enable effective mutual assistance and extradition." ${ }^{21}$ Article 4 deals with jurisdictional matters, including a requirement for parties to consult with each other when

\footnotetext{
${ }^{16}$ The Convention on Combating Bribery of Foreign Public Officials in International Business Transactions available at: http://www.oecd.org/dataoecd/4/18/38028044.pdf (last visited Apr. 29, 2009).

${ }^{17}$ Christopher F. Corr and Judd Lawler, Damned if You Do, Damned if You Don't? The OECD Convention and the Globalization of Anti-bribery Measures, 32 VANDERBILt Journal of TRANSNATIONAL LAW (VAND. J. TRANSNAT'L L.) 1249, 1303-04 (Nov. 1999).

${ }^{18}$ The OECD Convention on Combating Bribery, Art. 1.

${ }^{19}$ Commentaries on the Convention Combating Bribery of Foreign Public Officials in International Business Transactions, United States Senate Treaty Document (S. Treaty) No. 105-43, 22 (Nov. 1997).

${ }^{20}$ The OECD Convention on Combating Bribery (note 18), Art. 2.

${ }^{21}$ The OECD Convention on Combating Bribery (note 18), Art. 3(1).
} 
more than one party has jurisdiction over an alleged offense. ${ }^{22}$ Article 5 requires parties to enforce the convention without being "influenced by considerations of national economic interest." ${ }^{23}$ Article 6 states that any statute of limitations must allow for an "adequate period" for investigation and prosecution. ${ }^{24}$ Articles 7 and 8 address money laundering and accounting. ${ }^{25}$ Article 9 provides for mutual legal assistance and requires parties to offer "prompt and effective legal assistance to another Party" for both criminal and non-criminal investigations that fall within the scope of the OECD Convention. ${ }^{26}$ Article 10 requires each party to include bribery of a foreign official as an extraditable offense under its own laws and in extradition treaties among parties. ${ }^{27}$ Article 11 provides that the Secretary-General of the OECD shall serve as a "channel of communication" for matters that require parties to consult (such as Article 9 on mutual assistance). ${ }^{28}$ Article 12 establishes the OECD Working Group on Bribery in International Business Transactions as a means for systematically monitoring the implementation of the Anti-Bribery Convention. ${ }^{29}$

One distinguishing characteristic of the OECD Anti-Bribery Convention is its in-depth-and public-peer review process. The OECD regularly reviews each party's implementation and enforcement of anti-bribery laws and policies. ${ }^{30}$ Since the late 1990s, the OECD has conducted 150 investigations resulting in sanctions against over 60 individuals and companies. $^{31}$

\section{United Nations Convention Against Corruption}

\footnotetext{
${ }^{22}$ The OECD Convention on Combating Bribery (note 18), Art. 4(3).

${ }^{23}$ The OECD Convention on Combating Bribery (note 18), Art. 5.

${ }^{24}$ The OECD Convention on Combating Bribery (note 18), Art. 6.

${ }^{25}$ The OECD Convention on Combating Bribery (note 18), Arts. 7-8.

${ }^{26}$ The OECD Convention on Combating Bribery (note 18), Art. 9(1).

${ }^{27}$ The OECD Convention on Combating Bribery (note 18), Art. 10(1)

${ }^{28}$ The OECD Convention on Combating Bribery (note 18), Art. 11.

${ }^{29}$ The OECD Convention on Combating Bribery (note 18), Art. 12. See also The Annual Report of the OECD Working Group on Bribery available at: http://www.oecd.org/dataoecd/21/15/40896091.pdf (last visited on Apr. 29, 2009).

${ }^{30}$ See, e.g., OECD Working Group on Bribery, 8-9 (Annual Report 2007).

${ }^{31}$ Id. 9.
} 
The United Nations Convention Against Corruption (UNCAC) entered into force in $2005 .{ }^{32}$ UNCAC is extensive in its scope and coverage-it is 65 pages long comprising eight chapters and 71 articles- - and the document is uncompromising in its approach. The Forward begins with the stark statement, "[c]orruption is an insidious plague that has a wide range of corrosive effects on societies. It undermines democracy and the rule of law, leads to violations of human rights, distorts markets, erodes the quality of life and allows organized crime, terrorism and other threats to human security to flourish.",33

The first chapter lays out general provisions, including a statement of purpose and relevant definitions. ${ }^{34}$ The second chapter outlines preventive measures state parties must take, which include developing and implementing effective anti-corruption policies, periodically evaluating "relevant legal instruments and administrative measures" to determine whether they are adequate to fight corruption and collaborating with other state parties in promoting anti-corruption measures. ${ }^{35}$ The second chapter also requires state parties to ensure that appropriate bodies exist to prevent corruption and requires each particular state party to inform the General Secretary of the relevant names and addresses of its own authorities implementing anti-corruption measures. ${ }^{36}$ The second chapter goes into great detail about the requirements for effectiveness and transparency in the public sector ${ }^{37}$ and also describes measures state parties should take to prevent corruption in the private sector. $^{38}$

The third chapter addresses criminalization and law enforcement, including the requirement for each state party to adopt legislation criminalizing bribery of national public officials, foreign public officials and officials of public international organizations. ${ }^{39}$ The third chapter also suggests that state parties criminalize bribery and corruption in the private sector. ${ }^{40}$ The fourth chapter requires state parties to cooperate in criminal matters and suggest state parties "shall consider" assisting each other in civil and administrative

32 United Nations Convention Against Corruption available at: http://www.unodc.org/documents/treaties/ UNCAC/Publications/Convention/08-50026_E.pdf (last visited Apr. 29, 2009).

${ }^{33}$ Id., iii.

${ }^{34}$ United Nations Convention Against Corruption (note 32), Ch. I, Arts. 1-4.

${ }^{35}$ United Nations Convention Against Corruption (note 32), Ch. II, Art. 5.

${ }^{36}$ United Nations Convention Against Corruption (note 32), Ch. II, Art. 6.

${ }^{37}$ United Nations Convention Against Corruption (note 32), Ch. II, Arts. 7-11.

${ }^{38}$ United Nations Convention Against Corruption (note 32), Ch. II, Art. 12.

${ }^{39}$ United Nations Convention Against Corruption (note 32), Ch. III, Arts. 15-16.

${ }^{40}$ United Nations Convention Against Corruption (note 32), Ch. III, arts. 21-22. 
proceedings as well. ${ }^{41}$ The fifth chapter focuses on measures financial institutions must take to verify customers' identities in order to prevent illegitimate financial transactions and mechanisms that can be taken to recover property acquired through corrupt acts. ${ }^{42}$ The sixth chapter deals with training personnel to combat corruption and with the exchange of such information among state parties. ${ }^{43}$ The final two chapters address mechanisms for implementing the UNCAC and various other procedural provisions. ${ }^{44}$

\section{Regional Anti-Corruption Conventions ${ }^{45}$}

\section{The Organization of American States Inter-American Convention Against Corruption}

The Organization of American States (OAS) approved the Inter-American Convention Against Corruption (IACAC) on March 29, 1996. ${ }^{46}$ The IACAC was the first regional legal framework aimed at eliminating bribery and corruption of government officials. ${ }^{47}$ The IACAC seeks to "prevent, detect, punish and eradicate" official corruption in all the signatory states. ${ }^{48}$ The IACAC also seeks to facilitate cooperation among OAS member states in combating corruption.

The IACAC can be divided into two parts: domestic and multilateral. Article VII, which contains the mandatory domestic measures, requires all state parties, who have not already done so, to criminalize acts of corruption, including: (a) a public official soliciting or accepting "any article of monetary value, or other benefit" in "exchange for any act or omission in the performance of his public functions;" (b) offering any such bribe to a public official, directly or indirectly; (c) any act or omission by a public official for the purpose of "illicitly obtaining benefits for himself or for a third party;" (d) fraudulently using or

\footnotetext{
${ }^{41}$ United Nations Convention Against Corruption (note 32), Ch. IV, art. 43.

${ }^{42}$ United Nations Convention Against Corruption (note 32), Ch. V.

${ }^{43}$ United Nations Convention Against Corruption (note 32), Ch. VI.

${ }^{44}$ United Nations Convention Against Corruption (note 32), Chs. VII and VIII.

${ }^{45}$ For a review of individual state laws, see the report from the Working Group on Bribery in International Business Transactions available at: http://www.oecd.org/dataoecd/50/33/1827022.pdf (last visited Apr. 29, 2009).

46 The Inter-American Convention Against Corruption available at: http://www.oas.org/juridico/ english/Treaties/b-58.html (last visited Apr. 29, 2009).

47 Lucinda A. Low, The Inter-American Convention Against Corruption: A Comparison with the United States Foreign Corrupt Practices Act, 38 VIRGINIA JOURNAL OF INTERNATIONAL LAW (VA. J. INT'L L.) 243, 246 (Spring 1998).

${ }^{48}$ Inter-American Convention Against Corruption, 29 March 1996, Art. II.
} 
concealing property "derived from any acts referred to in this article;" and (e) participating after the fact in any way with "any of the acts referred to in this article." 49

Article VIII focuses on "Transnational Bribery." This article requires state parties to prohibit their own nationals from bribing government officials of another state. In states in which transnational bribery is an offense, "such offense shall be considered an act of corruption for the purposes of this Convention." In states where transnational bribery is not established as an offense, those states "shall, insofar as [their] laws permit, provide assistance and cooperation with respect to this offense." ${ }^{50}$

\section{Council of Europe Criminal and Civil Law Conventions on Corruption}

In 1999, the Council of Europe (COE) adopted two conventions addressing corruption: the CoE Criminal Law Convention on Corruption and the CoE Civil Law Convention on Corruption. $^{51}$

The CoE Criminal Law Convention covers three basic categories. First, it obligates parties to criminalize active and passive bribery ${ }^{52}$ of both domestic and foreign public officials (which includes officials of international organizations, members of international parliamentary assemblies, judges and court officials, as well as persons working in the private sector). ${ }^{53}$ The CoE Criminal Convention also requires parties to criminalize "trading in influence," money laundering and accounting offenses connected with corruption. ${ }^{54}$ Second, the CoE Criminal Convention requires parties to provide mutual assistance and facilitate extradition and confiscation of the proceeds in relation to corruption. ${ }^{55}$ Finally, $^{2}$

\footnotetext{
${ }^{49}$ Id., Art. IV.

${ }^{50}$ Inter-American Convention Against Corruption (note 48), Art. VIII.

51 Council of Europe Criminal Law Convention on Corruption available at: http://conventions.coe.int/ Treaty/EN/Treaties/Html/173.htm (last visited Apr. 29, 2009) and Council of Europe Civil Law Convention on Corruption available at: http://conventions.coe.int/Treaty/en/Treaties/Html/174.htm (last visited Apr. 29, 2009).

${ }^{52}$ The CoE Criminal Convention defines "active bribery" as "the promising, offering or giving, directly or indirectly, of any undue advantage to any persons who direct or work for, in any capacity, private sector entities, for themselves or for anyone else, for them to act, or refrain from acting." See Council of Europe Criminal Law Convention on Corruption, Ch. II, Arts. 2 (public officials) and 7 (private sector employees). "Passive bribery" is "the request or receipt" by a person "directly or indirectly, of any undue advantage, for himself or herself or for anyone else, or the acceptance of an offer or promise of such an advantage, to act or refrain from acting. See Council of Europe Criminal Law Convention on Corruption, Ch. II, Arts. 3 (public officials) and 8 (private sector employees).

${ }^{53}$ Council of Europe Criminal Law Convention on Corruption, Ch. II, Arts. 2-11.

${ }^{54}$ Id., Ch. II, Arts. 12-14.

${ }^{55}$ Council of Europe Criminal Law Convention on Corruption (note 53), Ch. II, Arts. 21-23 and Ch. IV, Arts. 25-31.
} 
the CoE Criminal Convention requires each party to allow the Group of States Against Corruption (GRECO) to monitor implementation of the Convention. ${ }^{56}$

The CoE Civil Convention is less expansive than its criminal counterpart. It defines corruption as "requesting, offering, giving or accepting, directly or indirectly, a bribe or any other undue advantage or prospect thereof, which distorts the proper performance of any duty or behaviour required of the recipient of the bribe, the undue advantage or the prospect thereof. ${ }^{\prime 57}$ It makes three important substantive efforts. First, it requires states to provide legal remedies (including compensation for damages) for those who have suffered damages as a result of corruption. ${ }^{58}$ Second, it requires international cooperation among the parties. ${ }^{59}$ Finally, like the Criminal Convention, the Civil Convention requires parties to be subjected to GRECO monitoring. ${ }^{60}$

\section{African Union Convention on Preventing and Combating Corruption}

In 2006, the African Union Convention on Preventing and Combating Corruption (AU Corruption Convention) entered into force. ${ }^{61}$ The AU Corruption Convention acknowledges that there is the need to "address the root causes of corruption on the continent" and "formulate and pursue, as a matter of priority, a common penal policy aimed at protecting society against corruption." ${ }^{62}$ The AU Corruption Convention covers a range of issues obligating parties to take three essential steps: prevent corruption, criminalize corruption and cooperate with other $\mathrm{AU}$ members on matters of corruption. ${ }^{63}$

The measures to prevent corruption require public officials to "declare their assets at the time of assumption of office during and after their term of office in the public service," to

\footnotetext{
${ }^{56}$ Council of Europe Criminal Law Convention on Corruption (note 53), Ch. III, Art. 24.

${ }^{57}$ Council of Europe Civil Law Convention on Corruption, 27 January 1999, Ch. I, Art. 2.

${ }^{58}$ Id., Ch. I, Arts. 3-4. See also, Timothy W. Schmidt, Sweetening the Deal: Strengthening Transnational Bribery Laws Through Standard International Corporate Auditing Guidelines, 93 MinnesOtA LAW REVIEW (MINN. L. ReV.) 1120, 1128 (Feb. 2009) ("The private right of action is unlike anything found in either the OECD Convention or the FCPA.").

${ }^{59}$ Council of Europe Civil Law Convention on Corruption (note 57), Ch. II, Art. 13.

${ }^{60}$ Council of Europe Civil Law Convention on Corruption (note 57), Ch. II, Art. 14.

61 African Union Convention on Preventing and Combating Corruption available at: http://www.africaunion.org/Official_documents/Treaties_\%20Conventions_\%20Protocols/Convention\%20on\%20Combating\%20Cor ruption.pdf (last visited Apr. 29, 2009).

${ }^{62}$ African Union Convention on Preventing and Combating Corruption, 2.

${ }^{63}$ Id. arts. 4-24; see generally Thomas R. Snider and Won Kidane, Combating Corruption Through International Law in Africa: A Comparative Analysis, 40 CORNELL INT'L L.J. 691 (Fall 2007).
} 
create bodies to implement and monitor codes of conduct for public servants and to maintain accounting, auditing and monitoring systems. ${ }^{64}$ The AU Corruption Convention also addresses preventing private corruption, including adopting legislation to combat corruption in the private sector, establishing mechanisms to "encourage participation by the private sector in the fight against unfair competition, respect of the tender procedures and property rights," and adopting measures "necessary to prevent companies from paying bribers to win tenders." ${ }^{65}$

The AU Corruption Convention criminalizes any public official or any other person soliciting or accepting, directly or indirectly, "any goods of monetary value, or other benefit, such as a gift, favour, promise or advantage for himself or herself or for another person or entity, in exchange for any act or omission in the performance of his or her public functions." ${ }^{16}$ Thus, the AU Corruption Convention criminalizes both demand and supply sides (the "offering" and "granting" of benefits). ${ }^{67}$

Finally, the AU Corruption Convention facilitates international cooperation among parties by creating national authorities for mutual legal assistance on corruption matters and by establishing an advisory board on corruption. ${ }^{68}$ The purpose of the advisory board, among other things, is to document corruption in Africa (including the "behaviour of multinational corporations operating in Africa") and to advise governments on how to fight corruption. ${ }^{69}$

\section{Law Firm Responses}

Anti-corruption regimes now cover most of the globe. For anyone doing business in a state that is party to any, or several, of these conventions, understanding the similarities and differences between the laws is critical to avoiding expensive penalties and even jail time. Government regulators are active and clients are worried. Providing advice to clients concerning anti-corruption regulations has become a legal cottage industry over the last few decades.

\footnotetext{
${ }^{64}$ African Union Convention on Preventing and Combating Corruption Arts. 7(1)-(2) and 5(4).

${ }^{65}$ Id., Art. 11.

${ }^{66}$ African Union Convention on Preventing and Combating Corruption (note 64), Art. 4(1).

${ }^{67}$ African Union Convention on Preventing and Combating Corruption (note 64), Art. 4(1)(b).

${ }^{68}$ African Union Convention on Preventing and Combating Corruption (note 64), Arts. 19-20 and 22.

${ }^{69}$ African Union Convention on Preventing and Combating Corruption (note 64), Art. 22.
} 
Each one of the 25 largest U.S. law firms has a dedicated practice group to provide counsel to clients on anti-corruption issues, which can include anything from helping with internal investigations to dealing with government regulators to litigation. ${ }^{70}$ Baker \& McKenzie, the largest U.S. law firm with over 3,000 lawyers worldwide, advertises its strength in helping clients navigate international treaties and regimes that "continue to expand while local public and commercial laws remain disparate. A patchwork whose complexity is constantly increasing." ${ }^{71}$ DLA Piper, the second largest law firm in the United States, has a "Regulatory and Government Affairs" practice group that provides specialists from Austria, Belgium, Bulgaria, China, Georgia, Hong Kong, Latin America, the Netherlands, Norway, Poland, Romania, Russia, Spain, UAE-Dubai, Ukraine, the United Kingdom and the United States. ${ }^{72}$ Jones Day touts on its website its representation of Northrop Corporation "in the

\footnotetext{
${ }^{70}$ Research was based on the websites of the largest American law firms according to America's Largest 250 Law Firms available at: http://www.ilrg.com/nlj250 (last visited Apr. 29, 2009). See footnotes 70-80 and Holland \& Knight available at: http://www.hklaw.com/id16048/mpgid4764/ (Foreign Corrupt Practices Act); WilmerHale available at: http://www.wilmerhale.com/litigation/foreign_corrupt_practices_act/ (Foreign Corrupt Practices Act); Weil Gotshal available at: http://www.weil.com/investigations-criminal-defense/ (Investigations and Criminal Defense, including FCPA); Kirkland \& Ellis available at: http://www.kirkland.com/sitecontent.cfm? contentID=218\&itemID=781 (FCPA and OECD); Morrison \& Foerster available at: http://www.mofo.com/practice/ practice/litigation/securitieslitigation/overview.html (anti-kickback case); McDermott Will \& Emery available at http://www.mwe.com/index.cfm/fuseaction/sub_areas.detail/object_id/6a1bc687-06f0-4d6c-a129-

a0c3ace93ed2/practice_area_id/0042458a-1ae2-437e-80eb-b2a7e69f60a5/long/1.cfm (FCPA investigations); Shearman \& Sterling available at: http://www.shearman.com/practices/detail.aspx?practiceid=5b60d2c9-aaa04ae0-9369-ab8a283424e1 (FCPA and Global Anti-Corruption Compliance); Kirkpatrick \& Lockhart Nicholson Graham available at: http://www.klgates.com/practices/ServiceDetail.aspx?service $=53$ (white collar crime/criminal defense, including FCPA); Hogan \& Hartson available at: http://www.hhlaw.com/whitecollar/ (FCPA investigations); Reed Smith available at: http://www.reedsmith.com/practice_areas_\&_ industry_groups.cfm?widCall1=customWidgets.content_view_1\&cit_id=23484\&cta_tax_id=14172 (Global Regulatory Enforcement); O'Melveny \& Myers available at: http://www.omm.com/whitecollar/ (white collar defense and corporate investigations including FCPA investigations); Akin Gump Strauss Hauer \& Feld available at: http://www.akingump.com/services/ServiceDetail.aspx?service=296 (white collar criminal defense including FCPA defense in Afghanistan, Angola, Argentina, Austria, Azerbaijan, Bahrain, Belarus, Bosnia, Brazil, Cambodia, Canada, Chile, China, Colombia, Congo, Cote d'Ivoire, the Czech Republic, the Dominican Republic, Egypt, England, France, Germany, Ghana, Greece, India, Indonesia, Iran, Iraq, Japan, Kazakhstan, Kyrgyzstan, Libya, Liechtenstein, Mexico, Nigeria, Pakistan, Peru, the Philippines, Romania, Russia, Sao Tome and Principe, Saudi Arabia, South Africa, Switzerland, Tajikistan, Tanzania, Uganda, Ukraine, United Arab Emirates, Uzbekistan, Vietnam, Zaire and Zambia); Paul Hastings available at: http://www.paulhastings.com/PracticeAreaDetail.aspx?PracticeAreald=32 (white collar, internal investigations and corporate governance); Foley and Lardner available at: http://www.foley.com/services/practice_detail.aspx?practiceid=403 (white collar defense); Fulbright \& Jaworski available at http://www.fulbright.com/index.cfm?fuseaction=description.subdescription\&site_id=427\&id=539 (white collar crime: special skills, including FCPA representation) (last visited Apr. 20, 2009).

71 Baker \& McKenzie, Trade \& Commerce available at: http://www.bakernet.com/BakerNet/Practice/ TradeCommerce/default.htm (last visited Apr. 16, 2009).

72 DLA Piper, Regulatory and Government Affairs available at: http://www.dlapiper.com/global/services/ detail.aspx?service=74 (last visited Apr. 16, 2009).
} 
1980s involving allegations of overseas bribery."73 White \& Case's White Collar group explicitly states:

"An important trend in business enforcement in the new decade is the rapidly increasing cooperation among national and multinational enforcement authorities. Officials in Washington, Brussels, London, Tokyo and other jurisdictions are sharing information at an unprecedented rate. [. . .] These matters are often pursued simultaneously in multiple jurisdictions and require a national and transnational network of legal resources to properly defend client interests." ${ }^{174}$

White \& Case further advertises its expertise in handling enforcement and defense in public and private corruption, as well as helping clients through international government investigations and inquiries in the United States, Europe, the Middle East and Asia. ${ }^{75}$

Latham \& Watkins claims expertise in FCPA violations. ${ }^{76}$ Skadden advertises its "extensive practice in advising and defending clients in matters involving the United States Foreign Corrupt Practices Act (FCPA) and related international laws, including the OECD AntiBribery Convention" and claims that the firm is "uniquely positioned" to help clients in "navigating the legal landscape when business conduct results in concurrent criminal, civil and/or administrative proceedings that require a strategically coordinated response."77 Sidley Austin presents its "extensive experience representing clients with respect to the U.S. Foreign Corrupt Practices Act" as well as "significant" experience in the laws of other countries "which relate to dealing with government officials." ${ }^{78}$ Greenberg Traurig warns potential clients on its website that "[r]ecent events have illustrated that the government has taken an increasingly aggressive investigative posture toward businesses, especially those subject to government regulations" and offers clients its "ability to develop integrated 'global' solutions" in international trade. ${ }^{79}$ Mayer Brown advertises its

73 Jones Day, Government Regulation - Overview available at: http://www.jonesday.com/government_ regulation/ (last visited Apr. 16, 2009).

${ }^{74}$ White \& Case, White Collar available at: http://www.whitecase.com/whitecollar/ (last visited Apr. 16, 2009).

${ }^{75}$ Id.

76 Latham \& Watkins, White Collar and Government Investigations available at: http://www.lw.com/practices.aspx?page=practicedetail\&practice=55 (last visited Apr. 16, 2009).

77 Skadden, Foreign Corrupt Practices Act Defense available at: http://skaddenpractices.skadden.com/fcpa/ (last visited Apr. 16, 2009).

78 Sidley Austin, FCPA/Anti-Bribery available at: http://www.sidley.com/OurPractice/ServiceDetail.aspx ?Service=258 (last visited Apr. 16, 2009).

79 Greenberg Traurig, LLP, White Collar Criminal Defense available at: http://www.gtlaw.com/Experience/ Practices/WhiteCollarCriminalDefense (last visited Apr. 16, 2009). 
familiarity "with the complexities of multinational investigations in coordinating the work of foreign counsel in such investigations." ${ }^{80}$ Morgan Lewis touts its "cross-disciplinary team of lawyers to address every aspect of FCPA counseling and compliance." ${ }^{81}$

Law firms are not only advertising their anti-corruption expertise on their websites, but many firms regularly publish guides for clients seeking help with anti-corruption issues. ${ }^{82}$ It is not surprising that law firms are competing with each other for this business because it is largely recession-proof (government regulators will go after corruption regardless of the state of the economy) and because bringing in one client with an anti-corruption matter frequently leads to more work for the law firm (if a company has corruption issues in one part of the globe, government regulators will frequently ask the company to expand the scope of its internal investigation to other countries known to be prone to corruption). What is surprising is that law schools have not similarly responded to the new legal framework.

\section{Multi-Jurisdictional Legal Education}

After completing four years in college, a typical U.S. law student spends three years in law school. ${ }^{83}$ The first is dedicated entirely to "the basics" that vary little from school to school: Torts (actionable wrongful acts that are not covered by contract), Contracts, Civil Procedure (rules that govern who can sue whom and how, when and where they can do so), Property, Criminal Law and Constitutional Law (a history class of important United States Constitution cases).

In the second and third years, students generally may take "electives" (courses students choose themselves). With the exception of students who want to specialize in tax law, most students are more concerned with the grades they receive in courses than the

${ }^{80}$ Mayer Brown, Foreign Corrupt Practices Act available at http://www.mayerbrown.com/fcpa/ (last visited Apr. 16, 2009).

81 Morgan Lewis, Foreign Corrupt Practices Act available at: http://www.morganlewis.com/index.cfm/ fuseaction/practiceArea.detail/nodeID/a837b788-db43-44cf-9f9d-1a3937cdbbe8/practiceAreaID/D38AB29521C1-4F61-A2CE-3725A3AD7EE8 (last visited Apr. 16, 2009).

${ }^{82}$ See Shearman \& Sterling LLP, Danforth Newcomb, Recent Trends and Patterns in FCPA Enforcement, available at: http://www.shearman.com/files/upload/FCPA_Trends.pdf (last visited Apr. 16, 2009); Proskauer Rose LLP, Matthew S. Queler, Wendy Wu and Bettina Chin, Foreign Corrupt Practices Act-Best Practices available at: http://www.proskauerguide.com/law_topics/27/IV (last visited Apr. 16, 2009).

${ }^{83}$ See, supra, note 2 ("Thus, in contrast to virtually every other country, prospective lawyers in the United States commence their study of law in a professional school, after receiving an undergraduate degree. Students in other countries experience their first academic contact with the law as undergraduates, similar to students studying history, literature or philosophy. In other countries, the practicing bar assumes the major responsibility for accomplishing the transition of these students into practicing lawyers. Here, the bar's role is ill-defined."). 
substance of the courses themselves. It is during these last two years that U.S. law schools could offer students an issue-focused multi-jurisdictional curriculum. ${ }^{84}$

Thirty years ago, the American legal education system may have served its purpose because those required first-year courses, along with a strong apprenticeship system of the traditional partnership-based law firm, provided most of the tools necessary to practice law. In the last few decades, though, those required courses have failed to provide a strong foundation for many lawyers because what many lawyers do has become so specialized and because law firms have changed from smaller partnerships to large limited liability partnerships. Not only has there been a dramatic increase in legal specializations, but law firms have transformed from partnerships where junior lawyers were treated as apprentices to partners who spent serious time training junior lawyers to enormous legal services firms where junior lawyers are measured in terms of billable hours and partners, even if so inclined, have little or no time to train associates. ${ }^{85}$ The combination of the increasing legal specialization and the shift away from partner-training has left new lawyers more dependent than ever on the education and skills they receive at law school. Offering students a curriculum based on practical issue-specific areas of the law seems reasonable. For some issue areas, the curriculum must be multi-jurisdictional in approach if it is to be comprehensive.

For example, a student specializing in anti-corruption regimes could begin with an introductory comparative course. Such a course would provide an overview of the FCPA, the IACAC, the OECD Anti-Bribery Convention, the CoE Criminal and Civil Law Conventions on Corruption, the UNCAC and the AU Convention on Preventing and Combating Corruption. This course would include, among other things, comparisons of how the conventions define public officials, what acts are prohibited and which entities are obligated to comply with the conventions.

After the introductory course, a student would have the option of taking in-depth courses on conventions and state laws in each region of the world that would include such topics as relevant cases concerning the convention, an introduction to related law in the jurisdiction, an overview of the relevant legal system and the study of the social context of corruption in the jurisdiction. For example, a course on Europe would not only cover the CoE Conventions, but also the OECD, the UNCAC and the FCPA.

\footnotetext{
${ }^{84}$ See, supra, note 3 (" $[\mathrm{A}]$ student is far better off with a law school experience that comes as close as possible to an integrated combination of skills, knowledge and substantive law in one broad area-such as litigation or corporate transactions - than with a smorgasbord of unrelated courses, even if that student ends up practicing in an entirely different area.").

${ }^{85}$ See, supra, note 2 (Over the last century "the in-house clerkship form of legal education was increasingly incompatible with the needs of the emerging corporate law firms created to meet the complex needs of institutional clients.").
} 
The final course for a student specializing in anti-corruption regimes could be a case study seminar requiring the student to write an in-depth client memorandum providing concrete advice based on a hypothetical fact pattern. Students would be asked to analyze, for example, what liabilities a British bank, whose securities are traded on the New York Stock Exchange, has in a situation in which the bank is acting as an underwriter for a securities offering in Germany and has hired a consultant who may have bribed certain foreign officials in connection with the offering. The hypothetical situation would change to reflect the current state of the law and the final product would be similar to what many white collar lawyers provide their clients on a regular basis.

\section{E. Conclusion}

The market for legal services is dominated by clients needing global, specialized and regulatory counsel. Although legal education has long been limited by the borders of the states in which law schools exist, the transnational realities of the practice of law demand some adaptations. As is evident from Part I, there are many important differences among anti-corruption regimes, for example, whether (1) there is a private right of action, ${ }^{86}$ (2) private sector corruption is criminalized, ${ }^{87}$ (3) public officials have obligations to disclose their financial assets under their own laws, ${ }^{88}(4)$ there is a statute of limitations ${ }^{89}$ and (5) the definition of public official. ${ }^{90}$ Corporations must understand the differences among the regimes in order to create effective internal policies and respond appropriately when there may be misconduct. Large law firms appear to be aligning themselves internally in order to provide such counsel.

U.S. law school education, however, is not tracking this reality. Junior lawyers enter the workforce at global law firms in a world of legal specializations and cross-border regulatory regimes largely ill-prepared. Not only has anti-corruption regulation "gone global," but so, too, has anti-trust/competition law, food and drug regulations and environmental law.

As the analysis of law firm practice groups demonstrates, law firms based throughout the United States are providing clients with multi-jurisdictional advice. Perhaps it is time for U.S. law schools to reevaluate their course structure and offer students formal issue-area specializations, including multi-jurisdictional specializations when necessary. Offering

\footnotetext{
${ }^{86}$ See, supra, note 58.

${ }^{87}$ See, supra, notes 38 and 40.

${ }^{88}$ See, supra, note 64.

${ }^{89}$ See, supra, note 24 .

${ }^{90}$ Low, supra, note $47,265-74$.
} 
students the opportunity to gain practical skills in issue-specific areas not only will make them better lawyers once they graduate, but will also likely make them more effective lawyers because they will be practicing in an area of the law in which they not only have an interest, but also have the skill set necessary to succeed. 
